\title{
THE PRESENT STATUS OF THE GERM-CELL PROBLEM IN VERTEBRATES
}

\author{
By N. B. EVERETT \\ Department of Anatomy, University of Michigan, Ann Arbor, Michigan
}

(Received 20 October 1944)

\section{INTRODUCTION}

One of the basic biological ideas which still receives considerable attention in zoological circles revolves around the theory proposed by August Weismann (1834-1914) that there is a clear distinction between the soma and the germ plasm. The idea that the germ cells early separate from the soma and are unique in that they are the only cells capable of bridging the gap between successive generations has come to be known as the 'germ-track' theory of Weismann. This theory, like many others, has its dissenters as well as its supporters. Weismann based his theory upon his work on the Hydromedusae. This was soon followed by the work of others who investigated the problem in the same and in higher forms. Boveri ( 1887 ) from his study of the development of Ascaris supported the hypothesis, and similar studies on other invertebrates likewise gave support. To-day the early cleavage stages of Ascaris are generally used to illustrate the principle of early segregation of soma and germ plasm.

In the vertebrates the problem first received attention by Waldeyer ( 1870 ) who observed distinguishable germ cells in the so-called germinal epithelium of the chick, and he believed that this epithelium gave rise to the germ cells. Since this initial work by Waldeyer the germ-cell problem has been studied in the embryonic and post-embryonic stages of many of the vertebrate groups including man. In these numerous studies various approaches have been made and the conclusions reached have been far from uniform. As was pointed out by Everett (1943) in his work on the mouse the fundamental question to be answered is whether the definitive germ cells are derived from undifferentiated cells which are set aside early in development and which later migrate to the gonad, or whether they are merely transformed soma cells which originate in the gonad from time to time even in the adult.

It would be difficult to review the work of all who have approached the problem, and an attempt will be made to confine the discussion to the more pertinent investigations and to summarize and evaluate the conclusions reached.

\section{CRITERIA USED FOR IDENTIFYING GERM CELLS}

The criteria used by various authors for distinguishing the primordial germ cells of vertebrates vary somewhat in details, but in general all are in agree- ment that they are large cells with large clear nuclei and distinct cell and nuclear membranes. In addition, according to many, the cells contain a considerable amount of yolk material. Specific diagnostic characters have been used by many investigators such as the shape of the mitochondria, the nature of the Golgi apparatus and the attraction sphere, the presence and number of plasmosomes, specific staining reactions, notched nucleus, etc. The value of these characters naturally depends to a great extent upon the species used and the techniques employed; thus there is apparently no one distinctive criterion that can be used with certainty in the diverse forms.

The experience of various investigators as concerns mitochondria may be used to illustrate the unreliability of a single character as a distinguishing factor of the germ cells. Rubaschkin (1912) stated that in the guinea pig developing ova could be distinguished from the other cells of the ovary by the fact that the mitochondria were exclusively in the form of granules in the germ cells while in the somatic cells they were thread-like or rod-shaped. Firket (19I4) found that in the chick the form of the mitochondria were not constant for the germ cells, and Swift (1914) showed that the mitochondria of primordial germ cells in the chick were usually in the form of rods but frequently appeared as granules. However, Tschaschin (1910) described the mitochondria of primordial germ cells of the chick as exclusively granular. Kingery (1917) found that the mitochondria in the germ cells of the mouse were predominantly granular but that other cells had similar ones. Schaxel (I9II) pointed out a fact with which we are well familiar to-day, namely, that the shape of the mitochondria varies according to the methods of fixation and staining. Lewis $\&$ Lewis (19I5) also indicated that the shape of mitochondria might be affected by different methods of treatment.

\section{VIEWS HELD CONCERNING GERM CELL ORIGIN}

Florence Heys (I93I), in her review of the work relating to the origin of the germ cells, classified the investigators of the subject into four groups on a basis of the conclusions they had reached. Although the problem has received considerable attention since r93 I, and novel approaches have been made, the same grouping with some modification is still valid and may be stated as follows: (1) Those who deny an early segregation of the germ cells from the soma and 
contend that the only sex cells to appear are from the somatic epithelium of the gonad. (2) Those who recognize an early embryonic segregation of the germ cells but hold that these all degenerate and that the definitive reproductive elements arise from the germinal epithelium. This group recognizes a functional segregation for the lower forms and the appearance of primordial cells which degenerate in the more advanced vertebrates is believed to be a recapitulation of the primitive condition. (3) Those who recognize an early differentiation of the germ cells from the soma and believe that the early segregated cells become functional, but that they are supplemented by cells produced by the germinal epithelium. (4) Those who recognize an early embryonic segregation of the germ cells from the soma and believed that these segregated cells alone are the progenitors of functional reproductive cells.

The first three groups could be further divided into those who believe that the formation of sex cells from the somatic epithelium is confined to the embryonic or early post-embryonic life of the individual, and those who hold that the sex cells derived from the germinal epithelium are formed periodically or continually throughout the reproductive period.

The above grouping summarizes well the various opinions held regarding the origin of germ cells, but it does not give a complete picture because some investigators hold one view for a certain animal studied and often an opposite view for another form; some support different views for the separate sexes of one species and some express borderline opinions.

\section{(1) Those who deny a segregation of the germ cells}

Those who deny that there is an early segregation of the germ cells contend that there is no morphological basis for the Weismannian theory of germplasm continuity. According to these investigators primordial germ cells do not exist, and the definitive germ cells are later formed by a transformation of somatic cells contributed by the germinal epithelium. Many of this group consider the large cells, designated as primordial germ cells, to be ordinary somatic cells in different phases of activity. The most common opinion is that they are enlarged cells preparing for division.

Hargitt has been one of the chief proponents of the view that there is no early segregation of the germ cells. His investigations of the problem in the coelenterates led him to the conclusion that the germ cells first appear near the time of sexual maturity and that they may arise from body cells. On a basis of his observations he felt that the theory of continuity of the germ plasm must be discarded for the invertebrates and suggested that the same might be true for the vertebrates. To verify his opinion he studied the problem in the adult salamander (1924), in which he sought to find the relation of the so-called primordial cells to the functional germ cells periodically produced. In this study, which was confined to the male, Hargitt identified the germ cells by their polymorphic nucleus, size, staining reaction, presence of an attraction sphere, and in some instances by a surrounding capsule of stroma. He felt that the presence of these cells in the stroma was an indication that they were differentiated from the stroma cells. Furthermore, he emphasized that the proximity of these enlarged cells to the collecting ducts was an indication of their origin from this source. In studying the peritoneum of the testis he observed mitoses which contributed potential germ cells. These transformed epithelial cells, he believed, migrated into the underlying stroma where they formed spermatogonia. This further study led Hargitt to discard the theory of germ-cell continuity for both vertebrates and invertebrates. Later (1925, 1926, 1930) he investigated the germ-cell question in the rat from very early embryonic stages through sexual maturity and involving both sexes. In approaching this problem in mammals he emphasized the necessity of a thorough study of the germ cells through the entire period of ontogeny, which he had not done in his amphibian work. In his study of the embryonic rat material he recognized enlarged cells throughout most parts of the embryo similar to those observed by other workers in the gut, splanchnopleure, and dorsal mesentery and generally interpreted as primordial germ cells, but he felt that these enlarged cells were so widely distributed that they could not be looked upon as germ cells but rather as somatic cells which had failed to divide and could in no sense be the forerunners of the definitive sex cells. As for the germ cells, he found them developing later from the peritoneal covering of the genital ridge. The first evidence of their appearance was an enlargement in situ; later these enlarged cells migrated into the stroma. From his mammalian studies Hargitt reached the same conclusions as those derived from his previous work which can best be summarized by his own statement (1926): 'Personally, I believe biology would be greatly the gainer by dropping the germ plasm idea entirely and permanently.'

Simkins (1923) in quite an extensive treatise on the origin and migration of germ cells in the mouse and rat also presents evidence unfavourable to the continuity concept. He, too, recognized, at early stages in the development of the mouse, certain entodermal cells of the blastocyst with characteristics similar to those recognized as germ cells by other investigators, but like Hargitt he found these same types of cells in various positions in older embryos. He regards them as ordinary somatic cells in various phases of metabolism and mitosis and reports that the progenitors of the definitive sex cells arise by a proliferation of the germinal epithelium which begins during the 14th day of development. From his studies of the turtle (1925) and of man (1928) Simkins reached the same general conclusions as for the mouse and rat. 
Von Berenberg-Gossler (1914) reported that the so-called primordial germ cells first found in the splanchnopleure of the chick are probably not germ cells.

\section{(2) Those who admit an early segregation of germ cells but believe that these degenerate}

Among those who recognize an early differentiation of germ cells but believe them to degenerate and contend that the definitive germ cells arise secondarily from the germinal epithelium are Felix and B. Allen for the pig and rabbit, E. Allen, Firket, and Butcher for the mouse, Kingery, von Winiwarter and Sainmont, and others. The work of Firket (1914) on the chick, and later (1920) on mammalian material, has perhaps more than that of any other investigator promoted the theory that the primordial germ cells, which do appear only to degenerate later, should be considered as cells in a phylogenetic regression. He stated that in the chick the primordial germ cells appear as free cells in the mesenchymal tissue of the splanchnopleure and in the radix of the mesentery before the genital ridge appears. Some of these, he believed, migrated later and became embedded in the sex cords of the genital glands. He believed that most of these presumably degenerated and that the majority of the definitive sex cells arose from the epithelial elements of the sex glands. He conceded that it was possible that some of the primary germ cells produced ova or sperm since he found it impossible to distinguish between primary and secondary germ cells. Later, from his observations on albino rats, he also recognized two series of germ cells in the sex cords. The first cells, which were large, he called primary germ cells, and the other which were smaller he called epithelial germinative cells. In contrast to his observations on the chick, he found that in the rat two generations of cells were easily distinguished because the secondary germ cells did not appear until the primary ones had disappeared. These results were used by him as further support for his phylogenetic interpretation of the significance of the primordial germ cells. That is, the primordial germ cells degenerate sooner in the ontogeny of the rat than in the chick because the rat stands higher in the phylogenetic scale.

Kingery (1917) concluded from his investigations of the mouse ovary that there are two proliferations of cells from the germinal epithelium. The first, occurring before birth, he believed gave rise to the primitive germ cells all of which degenerate, and the second occurring from birth to near the period of sexual maturity gave rise to the definitive ova. After sexual maturity no more egg cells or follicle cells were observed to arise from the epithelium. He does not give the history of any germinal cells previous to those he observed arising from the germinal epithelium, and his primitive germ cells are probably not the same as those of others observed in much younger stages and in different sites within the embryo.
Kingery reached the same general conclusions as von Winiwarter \& Sainmont (r g09) who found that in the cat ovary there are two proliferations of cells from the germinal epithelium before birth which form medullary and cortical cords. The germ cells of these proliferations degenerate, and it is a third proliferation arising between three and four months of age which gives rise to the definitive ova. Von Winiwarter \& Sainmont used meiotic phases as the criterion of a germ cell, but with this point Kingery takes issue. Kingery described synizesis in the first proliferation of germ cells which he believed to degenerate, but he contends that the cells of the second or definitive one do not exhibit these phases. Kingery is rather critical of those who have traced primordial germ cells to the developing gonad and without further studies have concluded that these are the progenitors of the definitive sex cells. He is justified in his criticisms, but he can be just as severely criticized for beginning his study with $10 \mathrm{~mm}$. mice, which are beyond the critical stages when the germ cells were first observed by other workers.

Kingery in attempting to explain why the period during which the germinal epithelium proliferates germ cells is longer than that reported for the cat by von Winiwarter \& Sainmont, tries to correlate this phenomenon with the size of the ovaries in the two species. He suggests that since the mouse ovary is smaller it cannot at one time accommodate the full quota of germ cells. Furthermore, he mentions that the small size of the gland possibly explains why there is considerable degeneration of germ cells as well as of follicle cells in the mouse. Kingery gives no data to show that the cat ovary is proportionately larger than that of the mouse.

Another point which should receive attention concerns the complete degeneration of germ cells at particular periods as found by von Winiwarter \& Sainmont and supported by Kingery and others. There are no observers who deny that many germ cells degenerate throughout ontogeny, but few report a more or less complete disappearance of them and a replacement by a secondary proliferation.

\section{(3) Those who believe that germ cells arise both from primordial germ cells and from the soma}

The work of Brambell (1927) is somewhat typical of those who recognize primordial germ cells in the primordium of the germinal ridge and the adjacent mesenchyme at an early embryonic stage but who question that these are the sole progenitors of the definitive sex cells. In his study of the morphogenesis of the indifferent gonad and of the ovary of the rat Brambell observed typical large so-called primordial germ cells in the gut mesentery near the site of the genital ridge and in the mesenchyme beneath the genital ridge about the time the epithelium had begun to proliferate. His interpretation of these extraregional germ cells is unique in that he believes them to be formed in the germinal ridge and to migrate 
subsequently into the subjacent mesenchyme. He is not too definite in his assumption, but his failure to find them in the yolk sac influenced him to consider this possibility. He admits that his material was insufficient for a definite conclusion. He noted an absence of the cells in other parts of the embryo and found no indication of their degeneration. He was able to trace the development of these early germ cells into definitive sex cells. In addition, he observed the development of similar cells from the epithelium of the genital ridge, and that their proliferation continued until the fourth or fifth week after birth. He stated that it would be difficult to imagine that a sufficient number of germ cells could migrate into the genital ridge to account for the rapid increase in the number present in the gonads between the tenth and twelfth days. However, he did find that many of the germ cells within the developing gonad were undergoing mitosis.

It is difficult to harmonize Brambell's conclusions with his observations. He reports (p. 393) that 'the first indication of the formation of the germinal ridges is found in embryos nine days p.c. where a few of the so-called primordial germ cells occur beneath the peritoneal epithelium along the ventral border of the Wolffian body. At this time the epithelium is similar to that of the rest of the peritoneum and consists of a single layer of cells, but a few cells beneath its surface indicate the beginning of proliferation.' From this description of the germinal epithelium the conclusion that the observed primordial germ cells had been produced by it is hardly warranted.

The work of Humphrey on the urodeles is one of the most complete studies of the germ-cell problem in any one group of vertebrates. His study (1925) on Amblystoma revealed that primordial germ cells are first present in the mesoderm just lateral to the somites, later they are crowded medially against the entoderm, and during further growth shiftings of the mesoderm they are carried medially into the genital ridges. In agreement with Humphrey are Dustin (1907), B. Allen (I9II), Beccari (1922), and Burns (1925). On the other hand, Abramowicz (I913) and Bounoure (1925) contend that in Triton the germ cells first appear in the entoderm and that they migrate at an advanced stage into the mesoderm. Humphrey has substantiated his morphological findings by a series of experimental studies $(1927,1928,1929 b)$. By removing a strip of mesoderm on one side of the body from the level of somite 7 to that of somite 16 or 17 he found that after further development there was always a complete absence of germ cells on the operated side. The embryos used were younger than those in which germ-cell migration from the entoderm was described by Abramowicz and Bounoure. Further proof of the early mesodermal position of the germ cells was afforded by the differentiation of typical primordial cells in the isolated mesodermal strips when transplanted to the latero-ventral body wall of other embryos. In many grafts, recovered after 50-70 days' growth, no germ cells were found, and Humphrey believed this to be the result of degeneration. However, forty grafts out of seventyfour gave rise to a gonad. Another series of experiments involved the transplantation of mesodermal strips to an orthotopic position in other embryos. In these transplants the primordial germ cells were found in approximately normal numbers and gonads differentiated in a greater percentage of cases than in those transplanted to the lateroventral body wall. In this latter series the germ cells of the host were removed in preparing a site for the graft, and Humphrey was certain that the presence of germ cells in the graft could come only from the transplanted mesoderm. He was careful in all cases to isolate the mesodermal transplant from the underlying entoderm, hence he is convinced that the chance of entodermal tissue adhering to the germ cells was nil.

With regard to the position of the early germ cells in the anuran embryos Humphrey and most other workers agree that they first appear in the entoderm. However, there is some disagreement as to whether they first appear in a median position in the roof of the archenteron (Humphrey, and others), or whether they migrate medially from two lateral foci (Bounoure).

It appears therefore that among the Amphibia there is considerable evidence supporting the idea that germ cells arise early outside their definitive position. The question is, are these the progenitors of the functional sex cells, and if so, do they constitute the only source of their origin? From his urodele studies Humphrey emphasizes the importance of the primordial germ cells in the development of the sex gland, but he suggests the possibility of secondary origin from other elements. This suggestion was proposed as a result of experiments in which extensive genital ridges developed which lacked primordial germ cells. The author clarifies his position through a personal communication in which he states : 'These ridges were the result of partial removal of gonadal preprimordia and were continuous at one or both ends with gonadal regions containing germ cells. When older larvae were found to have germ cells in these previously sterile ridges it was concluded they must be of secondary type. Later study left me in doubt as to the earlier interpretation. The cells first concluded to be secondary could often as easily be accounted for on the basis of mitosis and spreadings of primordial germ cells from the end of the ridge in which the latter were present. Further, the possibly secondary germ cells could not be distinguished by their morphology from germ cells in that part of the gonad in which primordial germ cells were present.' In later experiments of Humphrey (193I) ovaries of Amblystoma were reduced to a rudimentary state by the influence of a testis in the same animal, but regenerated into ovaries essentially normal in structure when the testis was removed. He states (personal communication) 'so far as I could judge, however, 
the restoration of ovarian cortex appeared to result from multiplication of the few surviving germ cells rather than from a transformation of other cells into oogonia'. Thus, the author now feels that he has no convincing evidence for a secondary origin of germ cells in Amblystoma, but he points out that his observations do not exclude the possibility of secondary germ-cell formation.

Another significant contribution by Humphrey relates to the role of the primordial germ cells and the associated mesodermal elements in gonad development. He was unable to solve this problem by his experimental approach in urodeles because a removal of the primordial germ cells necessitated a removal of the pertinent mesoderm. Using anuran embryos (1933) he extirpated the intermediate mesoderm together with adjacent parts of the axial mesoderm before the germ cells had begun to migrate from the entoderm. He found that after such removal gonads developed in a considerable number of cases on the operated side. Thus he concluded that mesoderm which ordinarily does not enter into the constitution of a gonad does differentiate into covering epithelium, rete cords and stroma if it comes in contact with a mass of primordial germ cells.

Other investigators who postulate a dual origin for the germ cells for the forms they studied are Essenberg (1923), Butcher (1927, 1929), and McCosh (1928). The work of Kirkham (I916) is interesting in that he believes that the oogonia of the mouse are direct descendants of the primordial germ cells, but that spermatogonia are descendants of epithelial cells.

\section{(4) Those who believe that the early segregated cells are the only source of the definitive sex cells}

The evidence supporting the Weismannian principle in its strictest sense was first based largely upon studies made on invertebrates, but evidence obtained from studies on vertebrates is by no means lacking at present. In fact, the majority of the investigators on vertebrates have reached such conclusions. The indication is that in the invertebrates segregation occurs during early segmentation, while in the vertebrates the germ cells have usually been first observed in the entoderm at a very early stage, but have seldom been traced to cleavage stages.

The work of Nussbaum, which included a study of several vertebrates, beginning in 1880 , provided some of the early evidence supporting the theory that germ cells are in reality different from somatic cells. He found that there was an early segregation and subsequent migration of reproductive cells in the trout, frog, and chick, although these cells did not first appear at the same site in all three forms. Thus Nussbaum was one of the first to take issue with Waldeyer who held that germ cells arose from somatic cells of the germinal epithelium.

Representative forms of all classes of vertebrates have been studied for evidence of an early segregation of germ cells. However, without exception the same or closely related species have been used by other investigators in evidence against the theory of early segregation.

Eigenmann ( $189 \mathrm{I}$ ) recognized what he believed to be primordial germ cells in the fifth cleavage stage of the teleost Micrometrus, and this is the earliest that segregation has been observed in any vertebrate.

Okkelberg's investigation of the germ-cell history in the brook lamprey (192I) is the most extensive that has been made on any representative of primitive vertebrates. He first recognized germ cells as large yolk-laden cells which become included in the mesoderm at a time when it separates from the entoderm. Many of these were observed to degenerate, but others shift from a lateral position in the mesoderm to a median position, the site of the definitive gonad. This change of position was accredited to a shifting of the tissues and, to a lesser extent, to independent migration. Okkelberg concluded that in the lamprey the primordial cells provided the only source of the definitive reproductive cells.

Among the investigators of the Amphibia who have observed that the germ cells segregate early and are usually first observed in the entoderm are B. Allen (1907), Witschi (1914, 1929), Burns (1925), and Cheng (1932). These workers concluded that definitive sex elements arise from these early segregated cells. Bounoure (I934) traced the continuity of germ plasm in the frog from the fertilized egg to the formation of the primitive gonads. He observed 'germinal cytoplasm' which he considered as Golgi material near the inferior pole of the undivided egg. This material moves dorsally, and during cleavage it is incorporated in cells near the floor of the blastocoel. These cells are then designated as primordial germ cells. During subsequent development the primordial germ cells are described to move laterally around the walls of the archenteron and eventually unite to form a single strand above the primitive gut. From here the germ cells pass into the genital folds. Bounoure (r935) substantiated the reliability of his observations by irradiating with ultra-violet the inferior pole of freshly ovulated frog eggs. The genital glands of frogs which developed from these eggs were devoid of reproductive cells.

The reptiles have received less attention in connexion with the germ-cell problem than any other vertebrate group, but among the few who have sought a solution in this class are B. Allen (1904), Jarvis (I908) and Risley (1933). Allen's study of Chrysemys and Jarvis's study of Phrynosoma show the germ cells to be segregated early and to first appear in the entoderm. Risley from his study of Sternotherus found too that the germ cells have an entodermal origin in early embryonic stages. They were observed to migrate from the entoderm through the mesentery into the genital ridge where they gave rise to the germ cells of the indifferent gonads. The transposition of the primordial germ cells was believed to be due to certain mechanical alterations in the tissues during 
growth and to amoeboid movements of the individual germ cells.

Many workers have investigated the origin of germ cells in birds, and in contrast to the situation regarding the other vertebrates there is more general agreement in the conclusions reached with regard to this class. However, the views are not in complete harmony.

The work of Swift (1914) on the chick initiated a renewed interest in the problem and introduced a new concept which until the last few years has challenged the skill of morphological and experimental embryologists. Swift observed that the germ cells arise in an extra-embryonic site at about the twosomite stage, in a crescentic area anterior and anterolateral to the embryo at the margin of the area pellucida. The mesoderm had not reached this point at this early stage and the germ cells were situated between the ectoderm and entoderm. Through migration they were reported to enter the mesoderm, then the blood vessels, and were carried by the blood stream to the mesentery where they were deposited by the capillaries. Here they enter the splanchnic mesoderm and migrate by amoeboid movements to the site of the future gonad.

The work of Swift was repeated by others who obtained identical results. Perhaps the most thorough confirming work was that of Goldsmith (1928) who extended his study from the earliest embryonic stages to adult animals and was able to establish that the definitive sex cells were derived from the primordial wandering cells. Dantschakoff had noted entodermal wandering cells in her chick study, made previous to that of Swift, but she did not associate them with the sex cells. Later (I93I $a$ ) she restudied her material and identified the wandering entodermal cells as identical with the primordial sex cells described by Swift.

Blocker (1933), from an extensive study of the embryonic history of the germ cells in the English sparrow, reached the same general conclusion as that of Swift and Goldsmith for the chick. He states that the primordial germ cells give rise directly to the definitive elements and that their number is increased only by mitosis. He found no evidence that germ cells in the sparrow are derived from somatic sources.

After Swift had observed the germ cells to arise in an extra-embryonic region several investigators made attempts to test the validity of his interpretation by experimental means. The first attempt was made by Reagan (1916) who removed the area in which the germ cells first appeared, according to Swift, and let the operated embryos continue their development, to be checked later for the presence or absence of reproductive cells. Although he encountered several difficulties in keeping the embryos alive his efforts were in part successful. The operated embryos which survived were found to be without sex cells. In one chick which lived to near the time of hatching the reproductive duct system was present but there was an absence of germ cells.
Another attempt to test Swift's observations was made by Benoit (1930) who irradiated at an early stage the area in which the germ cells were described to arise. His subsequent study of these irradiated specimens also showed an absence of germ cells.

As a sequel to her morphological work, Dantschakoff et al. (193I) approached the problem in a manner comparable to that of Reagan and Benoit. For the embryonic castration she employed electric cautery and this seemed to be a superior technique. By destroying the crescentic germinal area she was able to obtain embryos without germ cells or with germ cells in reduced numbers, depending upon the amount of crescentic tissue destroyed. Furthermore, she found that when the germ cells were destroyed no gonads developed.

Willier (I926) and his associates began a series of experiments to test the validity of Swift's theory of the extra-gonadal origin of germ cells in the chick. His approach was to isolate portions of the blastoderm at critical periods in the developmental history of the primordial germ cells and to test these isolates in chorio-allantoic grafts for their power to form a gonad. The isolated parts used in the tests were the entire pellucid area including a small part or all of the germinal crescent, the entire pellucid area except for the head region and entire germinal crescent, the pellucid area between the fifteenth somite level and node, a small piece containing the primitive knot of the head process blastoderm, and gonad-forming areas from 29- to 4I-somite embryos. From these series of experiments he was ultimately successful in getting several gonads to develop and these were free of germ cells. Willier points out that these results supply strong evidence supporting the idea that the germ-cell crescent supplies the germ cells of the gonad. However, he adds that caution must be exercised in accepting the results as proof that the germ cells arise in the extra-gonadal region. He gives this warning because : (I) he found that a sterile gonad sometimes formed in an implant of the pellucid area which included the germ-cell crescent; (2) a sterile gonad may form from an implant of the gonadforming rudiment which contained germ cells at the time of transplantation; (3) germ cells appeared in a graft of a small median piece containing the anterior half of the node from a blastoderm of the headprocess stage. Willier is to be commended for his scientific analyses of these points and for his caution in drawing definite conclusions. His results, however, in general agreed with those of Reagan, Benoit, and Dantschakoff. The chief discrepancy between the results of Dantschakoff and Willier concerns the problem of gonad differentiation independent of primordial germ cells. Dantschakoff concluded that without the primordial cells a gonad would not differentiate, whereas Willier showed that the gonad rudiment has the power to develop into a sterile organ independently. He suggests that the treatment of the 
embryos as employed by Dantschakoff was responsible for her failure to get gonad development.

Mammalian studies also lend support to the theory that germ cells are differentiated early and subsequently migrate to the definitive position. The work of Vanneman ( 1917 ) is especially interesting in this connexion because the form used in her investigation was the polyembryonic armadillo. She found that the conspicuously large germ cells were first discernible along the entodermic wall of the blastocyst just preceding the primary bud stages. These were relatively few and not considered to be of significance. The definitive ones were observed to arise in a comparable position during the secondary bud stage and appeared in each of the four embryonic areas. Some of these divided and in the primitive streak stages pushed into the entoderm of the future gut. Here they remained until the $4 \mathrm{~mm}$. stage when they were observed to enter the mesenchyme surrounding the gut and from there they passed through the dorsal mesentery to reach the indifferent gonad at the $10 \mathrm{~mm}$. stage. The germ cells were at times amoeboid in shape and were believed to reach the gonad by independent migration. She concluded that the germinal elements arose independently in each of the four embryos and not from a prelocalized region of the early blastocyst. It is significant that the germ cells were found to arise from the entoderm of the blastocyst, which is analogous to the yolk-sac entoderm of lower vertebrates.

Hamlett (1935) plotted the distribution of primordial germ cells in a $4.5 \mathrm{~mm}$. human embryo and found them to be clustered ventral to the mid-gut and as isolated cells in the dorsal mesentery and in the genital ridges. He is of the opinion that the germ cells arise at the site of the observed aggregation and that they reach the genital ridges by amoeboid activity. Witschi (1944), from a study of twenty-three human embryos ranging from the 13 -somite to the $8 \mathrm{~mm}$. stage, found that the germ cells have an entodermal origin. The primordial cells were first observed in the entoderm of the yolk sac near the allantoic evagination. From this site they are transferred to the hindgut and then into the mesenchyme and through the mesentery toward the mesonephric folds. Witschi concluded that migration is accomplished by active movements of the individual cells and that the course of migration is determined by a specific substance produced by the peritoneum of the gonadal region. He found no evidence for a secondary germ-cell formation.

Other observers who have investigated the problem in mammals and have reached the same general conclusion, that the germ cells are first recognizable in the gut entoderm and subsequently migrate through the mesentery to reach the gonad, are Rubaschkin (1908, 1909), who studied the cat, rabbit and guinea-pig, and Everett (1943), who studied the mouse. Fuss (1913), from his studies of the rabbit, pig and man, concluded that the germ cells first appear in the region of the primitive streak. He also observed scattered cells in the yolk, and these were reported to migrate subsequently into the entoderm and through the mesoderm to the genital ridge.

B. Allen, who investigated the germ-cell problem in certain fishes, in the frog, and in the turtle, recognized an early segregation of primordial germ cells and their migration into the developing gonad. In all these forms the germ cells were first discernible in the gut entoderm. However, from his earlier study of the rabbit and pig he concluded that the functional germ elements arise from peritoneal cells. He recognized primordial germ cells in the mesentery of the alimentary canal in early stages but believed that these did not produce functional reproductive cells.

In view of the fact that morphological results in mammals have been interpreted so differently, Everett (1943) approached the problem experimentally in the mouse. As mentioned above, his morphological study revealed that germ cells first appear in the gut entoderm and that from here they migrate into the splanchnic mesenchyme and through the dorsal mesentery into the genital ridge. Transplants of the genital ridge to a host kidney before sex cells are present in it did not form any sex cells, although the transplant differentiated reproductive and mesonephric ducts. Transplants of the genital ridge after the sex cells had arrived differentiated into typical testicular or ovarian tissue. In excising the genital ridge primordia particular care was exercised to remove the gut and dorsal mesentery. Furthermore, embryos of the same age and size as that of the donors were used as controls. Everett concluded that without the primordial sex cells, derived from those of the gut entoderm, there is no subsequent development of sex cells. These results are in general agreement with those of Reagan, Benoit, Dantschakoff, Humphrey, and Willier. All who have approached the problem experimentally, with the possible exception of Kuschakewitsch, have come to the conclusion that germ cells have an extra-gonadal origin and that these cells are necessary for the later development of germinal tissue in the gonad. Kuschakewitsch (1910) prevented the germ cells of the frog from entering the germinal ridges by delaying the fertilization of overripe eggs. Sterile ridges were produced which later showed the presence of germ cells. These were interpreted by Kuschakewitsch as having transformed from indifferent cells of the developing testis. Witschi (1914) repeated the work of Kuschakewitsch, but he believed that the germ cells which appeared later were primordial germ cells which were delayed in their migration by the experimental procedure. Humphrey attempted to duplicate the work of Kuschakewitsch and Witschi without success.

IV. FORMATION OF GERM CELLS SUBSEQUENT TO SEXUAL MATURITY

Numerous studies have been made relating to the post-pubertal formation of reproductive cells. These studies have included both sexes in all of the major 
vertebrate groups, but the majority of the investigations concern the mammalian ovary.

Arai (1920), from his study of the rat ovary, suggested that there is a continuous proliferation of ova from the germinal epithelium through the period of sexual maturity. He found that the proliferation of new ova is most marked from 15 to 60 days after birth and thereafter proceeds at a slower rate. He observed that ova of all stages undergo degeneration and are replaced by the continuous epithelial proliferation.

E. Allen (1923), from an extensive study of mouse ovaries during the different phases of the oestrous cycle, concluded that new ova are added to the cortex from the germinal epithelium and that such addition occurs at each normal oestrous period. The stages he described for oogenesis in sexually mature forms were : mitosis in the germinal epithelium, followed by the presence of small ova just beneath the epithelium surrounded by a few follicle cells, and this condition was followed by young follicles at a distance of two cells below the surface of the ovary. Allen makes quite a point of these mitotic stages appearing in the epithelium and contends that a daughter cell of such a division may be added to the cortex and give rise to an ovum if the plane of the mitotic spindle is perpendicular to the surface of the ovary, or if the angle is not less than thirty degrees. He was convinced that these newly contributed cells form ova because he observed a marked increase in the number of ova just beneath the epithelium when mitosis was at its height, and there were few young ova after a long period of dioestrus when there is no mitotic activity in the epithelium.

Hargitt (1930) described two methods by which new ova are produced in the adult rat. One is by enlargement in the germinal epithelium of cells which become surrounded by smaller adjacent cells and migrate into the tunica albuginea to form young follicles. In other cases a number of epithelial cells round up into a mass and move into the tunica where one of the cells may enlarge to form an ovum while the rest form follicle cells. Everett (1942) concluded from a study of the ovary of the adult opposum that new ova are added continuously from the epithelium and that the epithelium is most active just preceding the breeding season. He also concluded from his study that new ova may be contributed by mitosis of epithelial cells and by enlargement of epithelial cells in situ.

Among other investigators whose mammalian studies support the theory that new ova are formed during sexual maturity are : Palladino (1894), Papanicolaou (1925), Butcher (1927), Evans \& Swezy (I93r), Stockard (1936), Guthrie \& Jeffers (1938), and Duke (194I, 1944). Evidence for continued oogenesis during adult life in forms below mammals has been given by Bouin (IgOI) and Gatenby (1916).

In contrast to the work of Allen and others, Cowperthwaite (1925) found from a study of an extensive series of rat ovaries, including birth stages to those well beyond sexual maturity, that there was no evidence for a cyclic formation of ova. He observed that meiosis was completed in the newborn by the fourth day post partum, and since he considered meiosis a necessary characteristic of germ cells concluded that oogenesis is not continued during later pre- or post-pubertal life. Furthermore, he did not observe any germinal epithelial cells to enlarge in situ after puberty.

Other investigators who hold that the germinal epithelium produces functional germ cells but that such formation is confined to the period before or near puberty are Foulis ( 1876 ), Rubaschkin (19r2), von Winiwarter \& Sainmont (1909), Waldeyer (1870), and Kingery (1917).

Thus there appears to be as great a diversity of opinion regarding the post-natal formation of germ cells as exists regarding their embryonic formation. This phase of the problem has also been approached experimentally with promising results. From time to time in medical literature reports have appeared of pregnancies following double ovariotomy in women, indicating regeneration of ovarian tissue. Davenport (I925) found that after what he believed to be a complete removal of ovaries in mice there was regeneration of germinal tissue. From this he concluded that somatic tissue could change into germ cells. Parkes, Fielding \& Brambell (1927) removed the ovaries, capsules and portions of the tubes from 12 I mice. Eleven of these later exhibited vaginal changes characteristic of oestrus. Histological study of the extirpated ovaries showed that removal had been complete; however, ovarian tissue was demonstrated in eight of the eleven mice, and this was interpreted as having been regenerated from somatic tissue.

Hooker \& Cunningham (1938) observed that after bilateral removal of the testis in the fowl some of the animals regenerated testicular tissue. They described occasional cords forming from the peritoneum in a manner comparable to that occurring in the embryo; thus they concluded that somatic tissue can change into germ cells.

Haterius (1928) obtained results comparable to the above but his interpretations were different. $\mathrm{He}$ removed both ovaries from ninety-six mice and in a few cases there was some ovarian regeneration which he believed to be due to an incomplete removal. $\mathrm{He}$ found that complete castration was not followed by epithelial proliferation of ovarian tissue; thus he concluded that in mice germinal tissue will not arise de novo from the coelomic epithelium.

The work of Heys (r93I) seemed to clear up the confused state regarding the capacity of somatic epithelial tissue to form germinal tissue in her experiments involving the removal of rat ovaries. Her results showed that young rats, after extirpation of the ovaries, never regenerated germinal tissue. However, older specimens frequently showed some ovarian regeneration. This discrepancy she believed 
to be due to the fact that in the young rats the ovary could be removed completely, whereas in the older specimens the ovaries were so disposed that it was very difficult to extirpate all of the gonadal tissue.

Illustrative of other experimental approaches in testing the capacity of the epithelium to form germ cells is the work of Long (194I). He isolated the germinal epithelium from the ovary of the mouse and cultured the isolate. He observed that from the epithelial cells ova developed, some of which formed primary follicles. As pointed out by Everett (1943) this appears to be an ideal approach to the problem, but it would seem to be practically impossible to isolate epithelial cells completely from germ cells that might be adhering, because the germ cells are in a sense located among the epithelial cells.

Everett ( I 943) made a series of ovarian transplants, with and without the bursa, to the kidneys of adult mice. The epithelium of those transplanted without the bursa fused with the kidney, and there was an apparent destruction of the germinal epithelium. In these there was no evidence that new ova were formed. The epithelium of the ovaries transplanted with the surrounding bursa intact frequently remained as a typical germinal epithelium without fusion. In these, young ova and follicles were observed to develop. These results indicated that the germinal epithelium played a vital role in the new formation of ova.

Another approach made by Everett (1943) was by the use of X-rays. It is a well-established fact that germinal tissue is quite susceptible to roentgen rays. With this in mind Everett irradiated female mice, confining the path of the rays to the area above the ovaries and hoping in this way to sterilize the sex glands with a view to subsequent study of the epithelium for signs of germ-cell proliferation. He found that 168 or more roentgen units of $X$-rays sterilized the ovaries and after a time the epithelium proliferated cords of cells, but these never produced any elements which resembled germ cells. He concluded that since the epithelium remained active without forming germinal tissue it was reasonable to assume that the somatic epithelial tissue is unable to form ova. There is the possibility, however, that the irradiation might have destroyed the capacity of the epithelial cells to form ova without destroying their ability to persist, divide, and form cord-like ingrowths. Of secondary interest he reported that these cords resembled the cords of the differentiating testis, a possible indication of a tendency towards sex reversal. This is comparable to the results of Brambell, Parkes \& Fielding (1927), who observed that after irradiating ovaries of mice there was a proliferation of cords from the epithelium which resembled the so-called spermatic cords.

Stschegolew (1934) showed that the gonocytes of the young rat testis are very sensitive to X-rays. After irradiation these cells stopped dividing and were soon eliminated. He further demonstrated that after application of $\mathrm{X}$-rays the non-germinal cells persisted for some time, and he points out that these are in no way similar in structure to sex cells. Thus his work shows that sperm or their progenitors do not originate from the somatic elements. In a later paper he reported that gonocytes are eliminated in the rat testis by a dose of $200-300 \mathrm{r}$.

\section{DISCUSSION}

From what has been presented it is obvious that the majority of investigators support the hypothesis that at some time during the life history of an animal the germinal epithelium gives rise to germinal elements. From this it might seem necessary to conclude that somatic cells possess the capacity to change into reproductive tissue. However, it is possible to reconcile this view with that of an early segregation. The experiments by Everett (1943) in which the ovaries were transplanted to the kidney indicated that ova are derived from the epithelium. On the other hand, his irradiation experiments indicated that the epithelium does not produce germ cells. The answer to these apparently conflicting results and views is to be found in the relation of the primitive germ cells to the epithelium of the gonad. In many cases cells are found which have the characteristics of germ cells, lying in close relation to the typical elongated or cuboidal cells of the germinal epithelium. The enlarged cells push against the mesothelium in such a way that its cells become somewhat flattened and attenuated. Thus it is possible to mistake such enlarged cells, which actually lie beneath the epithelium, as a part of the epithelial covering. A more thorough study of this point might pave the way for greater harmony among the various investigators regarding the germinal potentiality of the so-called germinal epithelium.

Assuming the above proposal to be correct there are still many problems to be considered, and some of these have been pointed out in the preceding pages. The experimental approaches favour the theory of an early segregation and subsequent migration. If this be correct it is possible that some of the germ cells which segregate early are lodged among the epithelial cells that cover the gonad. It would follow then that some of these migrate into the deeper substance of the gonad to become functional, some degenerate, some undergo mitosis to form additional germ cells, and some remain relatively dormant to become functional in the later life of the individual.

One of the major objections to the theory that germinal tissue is segregated early and that there is no new formation of reproductive elements later is that it is difficult to conceive of the cells as remaining dormant for months or years before they function in reproduction. In this connexion Allen (1923) among others has pointed out that there is a high mortality of the follicles. Furthermore, attention is directed to the increase in the production of ova near the breeding season. It is conceded that many developing follicles 
undergo degeneration throughout the life of the individual, but it cannot be concluded from this that a germ cell, which has not begun its transformation into a functional reproductive element, is necessarily in a physiological state that leads to an early death. It is also well to recall that the longevity of many cells, such as muscle cells, nerve cells, bone cells, etc., is greater than that ever attributed to germ cells. It is generally agreed that the cells of the seminiferous tubules are self-propagating in that spermatogonia which are adjacent to the basement membrane divide to form other spermatogonia. Whatever the source of the first spermatogonia might be it is not necessary to postulate a new formation from somatic elements throughout the reproductive life of the male. It is easy to conceive that the cells in the ovary lying in or near the epithelium are comparable to the spermatogonia in that they retain their capacity for selfpropagation. Furthermore, multiple examples can be given of cells which retain their primitive nature and produce definitive cells and cell products throughout the life of the individual. Typical examples are the haemocytoblast which forms definitive blood cells, and certain connective tissue cells which are called upon in tissue repair.

Another major objection that has been raised against the theory that germ cells are set aside at an early stage at a site removed from their ultimate position is that they must migrate to the developing gonad and that such migration is inconceivable because of numerous obstacles. This objection is not serious in view of the many apparently complex changes involved in the normal development of an individual. The migration of muscle masses, of nerve cells and their processes, of pigment cells, and the considerable shifting of cell masses during gastrulation and later stages are generally accepted as facts. Germ-cell migration falls in the same category of events. Woods (I902) and Bachman (I914) suggested that some chemical force is responsible for the migration of germ cells, but there may be other factors involved.

Simkins (1923) argues strongly against the idea that there is a continuity of the germ cells, and there is scarcely any evidence that has been presented in favour of the hypothesis which he does not attack. He states: "If we are to believe in the migration of germ cells, we must be prepared to accept the conclusion that certain cells, or classes of cells, are able to set out on a journey over several millimetres of intervening tissue, cross barriers and penetrate membranes, become carried away in the blood stream, perishing against obstacles they cannot surmount, until the survivors are at last safe in the fundament of the genital gland.' With regard to the several millimetres of tissue that he postulates the germ cells must cross, this might be true in birds. However, in mice, which is a form that he has studied, the distance from the gut where the germ cells first appear to the primordium of the gonad, which is the distance to be traversed at the time of presumed migration, varies from less than $\mathrm{I}$ to about $\mathrm{I} \frac{1}{\mathrm{~d}} \mathrm{~mm}$. Such a distance is of no consequence when one considers the movements and migrations that take place in many parts of a developing embryo. The distance that a developing follicle traverses before the ovum is emitted from the ovary is much greater, and a follicle, because of its size, age and situation, should be much less labile than a primordial germ cell. In regard to the membranes to be penetrated, as Simkins postulates, one might inquire what definite membranes are present in young, pliable embryonic tissue. Embryonic tissue is characterized by its lack of compactness, by its pliability, and by its intercellular spaces filled with fluid. A much more puzzling problem is how cells from the germinal epithelium, or cells just beneath the epithelium can, with their surrounding follicle cells, reach the deeper parts of the ovary. Yet this commonly described process is not questioned. These points are mentioned chiefly to emphasize the type of reasoning that is sometimes used without sufficient evidence in support of convictions.

Further experimental work is needed to solve the questions relating to the germ-cell problem and its many ramifications. This type of approach has already answered many of our biological problems, and it has definitely begun to pave the way for a common understanding of the Weismannian principle of germplasm continuity.

\section{SUMMARY}

(I) Morphological studies relating to the origin and differentiation of the definitive germ cells in vertebrates have, as indicated, resulted in conflicting views. In many instances two or more competent investigators who have studied the same form have reached different conclusions. (2) Some contend that the germ cells are set aside from the soma during the early stages of embryonic development, and that these alone serve as the progenitors of the functional sex cells. (3) Others recognize an early differentiation of sex cells but hold that these are supplemented by others produced from the somatic epithelium of the gonad in late embryonic or post-embryonic stages. (4) Another group recognizes the early differentiated cells as germ cells but contend that these all degenerate and that the definitive ones are formed from the germinal epithelium. These degenerating germ cells are believed by certain authors to be a phylogenetic recapitulation of the condition in lower forms. (5) Finally, yet another group contends that the so-called primordial germ cells are not germ cells at all but are enlarged cells in some stage of mitosis or in some specific metabolic phase. This group believes that all germ cells are derived from the somatic cells of the germinal epithelium. (6) Experimental work supports the view that the primordial germ cells, which are recognized early, are the progenitors of the definitive sex cells. When these primordial germ cells are prevented from reaching the site of the developing gonad the individual fails to develop sex cells, although a sterile gonad and its associated structures may develop. (7) I suggest that the observed proliferation of germ cells 
from the germinal epithelium, reported by numerous investigators, can be interpreted in another way by a thorough study of the enlarged germ cells in relation to the epithelium. It seems probable that the cells of the epithelium, which form functional sex elements, are not and never were a part of the mesothelial covering, but are cells which were segregated early, and are merely stored in the epithelium.

\section{REFERENCES}

Abramowicz, Helene (1913): Morph. $7 b .47,593$.

Allen, B. M. (1904): Amer. F. Anat. 3, 89. - (1906); Anat. Anz. 29, 217. - (1907): 31, 339. - (I91 I): F. Morph. 22, 1 .

Allen, Edgar (1923): Amer. F. Anat. 31, 439.

Arai, Hayato (1920): Amer. F. Anat. 27, 405.

Bachman, Freda M. (1914): Biol. Bull. Woods Hole, 26, $35 \mathrm{I}$.

BeCCARI, N. (1922): Arch. ital. Anat. Embriol. 18, 29.

Bknoit, J. (1930): Proc. 2nd Int. Congr. for Sex Res. pp. $162-70$.

von Berenberg-Gossler, H. (1914): Anat. Anz. 47, 241.

Blockrr, H. W. (1933): Acta Zool., Stockh., 14, I I I.

Воні, U. (1904): Morph. $\mathcal{F b} .32,505$.

Bourn, M. (I901): Arch. Biol., Paris, 17, 201.

Bounoure, L. (1925): Ann. Sci. nat. 8, 201. - (1934): 18, 67. - (1927): C.R. Acad. Sci., Paris, 184, 549. - (1935): 120, 1316. - (1939): L'Origine des Cellules Reproductrices et le Probleme de la Ligne germinale. Paris". - (1940): Continuité germinale et Reproduction agame. Paris".

Boveri, T. (1887): Fena. Z. Naturw. 21, 423.

Brambell, F. W. R. (1927): Proc. Roy. Soc. B, ror, 39 r.

Brambell, F. W. R., Parker, A. S. \& Fielding, Una (1927): Proc. Roy. Soc. B, ror, 29.

Burns, R. K. (1925): F. Exp. Zool. 42, 31.

Butcher, E. O. (1927): Anat. Rec. 37, 13. - (1929): Biol. Bull. Woods Hole, 56, 87.

Cheng, Tso-Hsin (1932): Z. Zellforsch. r6, 497.

Cowperthwaite, M. H. (1925): Amer. F. Anat. 36, 69.

DantschakofF, W. (1931): $Z$. Zellsforsch. 13, 448 . - (r932): 15, 581.

Dantschakoff, W., Dantschakoff, W. Jr. \& BeresKINA, L. (1931): Z. Zellforsch. 14, 323.

DAVENPORT, C. B. (1925): F. Exp. Zool. 42, 1.

Duke, K. L. (194I): F. Morph. 69, 5 r. - (1944): Anat. Rec. 89, 135 .

Dustin, A. P. (1907): Arch. Biol., Paris, 23, 4r I.

EigenmanN, C. H. (1891): $¥$. Morph. 5, 481 .

Essenberg, J. M. (1923): Biol. Bull. Woods Hole, 45, 46.

Evans, H. M. \& Swezy, O. (1931): Mem. Univ. Calif. 9, I 19.

Evrrett, N. B. (1942): Anat. Rec. 82, 77. - (1943): F. Exp. Zool. 92, 49.

FELIX, W. (1912): Human Embryology, Keibel and Mall, Philadelphia 2, 752.

Firket, J. (1914): Arch. Biol,, Paris, 29, 201. - (1920): Anat. Rec. 18, 309.

Foul1s, J. (1876): Quart. F. Micr. Sci. 16, 190.

Fuss, A. (I913): Arch. mikr. Anat. 81, 1.

Gatendy, J. B. (1916): Quart. F. Micr. Sci. 61, 275.

Goldsmith, J. B. (1928): F. Morph. 46, 275.

- These books were not available to the author.
Guthrie, M. J. \& JefFers, K. R. (1938): $\mathcal{F}$. Morph. 62, 523.

Hamlett, G. W. D. (r935): Anat. Rec. 6r, 273.

HARGitT, G. T. (rg19): $\mathcal{F}$. Morph. 33, I. - (1924): 39, 63. $-(1925): 40,517 .-(1926): 42,253$. $-(1930):$ 49, 277.

Haterius, H. O. (1928): Physiol. Zoöl. 1, 45.

Heys, Florence (1931): Quart. Rev. Biol. 6, I.

Hooker, C. W. \& Cunningham, Bert (1938): Anat. Rec. 72, 371 .

HuMPHREY, R. R. (1925): F. Morph. 41, 1. - (1927): F. Exp. Zool. 49, 363. - (1928): Anat. Rec. 40,67. - (1929a): 42, 301. - (1929b): F. Exp. Zool. 53, 171. - (193 I): Anat. Rec. 51, 135. - (1933): F. Exp. Zool. 65,243 .

JaRvis, MAy (1908): Biol. Bull. Woods Hole, I5, I 19.

KINGERY, H. M. (I9I7): $\mathscr{F}$. Morph. 30, 261.

Kirkham, W. B. (1916): Anat. Rec, 19, 217.

Kuschakewitsch, S. (1910): Festschr. f. R. Hertwig, 2, 6 I . Lewis, M. R. \& Lewis, W. H. (191 5): Amer.F. Anat. 17, 339.

Long, J. H. (194I): Contr. Embryol. Carneg. Instn, 28, no. 518 , p. 170 .

McCosh, Gladys (1928): Anat. Rec. 41, 78.

Nussbaum, M. (1880): Arch. mikr. Anat. 18, 1.

OKkelberg, P. (r921): $\mathcal{F}$. Morph. 35, 1.

Palladino, G. (r894): Arch. ital. Biol. 21, 208.

Papanicolaou, G. N. (1925): Proc. Soc. Exp. Biol. N. Y., $21,393$.

Parkes, A. S., Fielding, Una \& Brambell, F. W. R. (1927): Proc. Roy. Soc. B, ror, 328.

Reagan, F. P. (1916): Anat. Rec. I1, 251.

Risley, Paul L. (1933): Z. Zellforsch. 18, 459.

Rubaschkin, W. (1907): Anat. Hefte, 35, 24 1. - (1908): Anat. Anz. 32, 222. - (1909): 39,603. - (1912): 46, 343.

Schaxel, J. (rgir): Anat. Anz. 39, 337.

Simkins, C. S. (1923): Acta Zool., Stockh., 4, 241. - (1925): Amer. F. Anat. 36, 185. - (1928): 41, 249.

Stockard, A. H. (1936): Pap. Mich. Acad. Sci. 22, 671.

Stschegolew, G. G. (1934): Arch. russes Anat. Histol. Embryol. I3, 309.

SwifT, C. H. (1914): Amer. F. Anat. 15, 483 .

Tschaschin, S. (1910): Anat. Anz. 37, 597.

Vanneman, A. S. (1917): Amer. F. Anat. 22, 341.

WALDEYER, W. (1870): Eierstock und Ei. Leipzig.

Weismann, August (1904): Vorträge über Descendenztheorie. English Translation. London.

Willier, B. H. (1926): Anat. Rec, 34, I 58 . - (1937): 70,89 .

von Winiwarter, H. \& Sainmont, G. (1909): Arch. Biol., Paris, 24, I.

Witschi, EmIL (I914): Arch. mikr. Anat. 85, 9. (1929): F. Exp. Zool. 52, 235. - (1944): Anat. Rec. 89 (Suppl.), 5.

Woods, F. A. (1902): Amer. F. Anat. 1, 307. 